\author{
A. Shyshatskyi ${ }^{1}$, Yu. Zhuravskyi ${ }^{2}$, O. Kuvshinov ${ }^{3}$, T. Hurskyi ${ }^{4}$, R. Vozniak ${ }^{3}$, R. Pikul ${ }^{3}$,O. Pikul ${ }^{3}$ \\ ${ }^{1}$ Central Research Institute of Weapons and Military Equipment of Armed Forces of Ukraine, Kyiv, Ukraine \\ ${ }^{2}$ Zhytomyr Military Institute named after S. P. Korolev, Zhytomyr, Ukraine \\ ${ }^{3}$ National Defence University of Ukraine named after Ivan Chernyakhovsky, Kyiv, Ukraine \\ ${ }^{4}$ Military institute of telecommunications and informatization named after Heroes of Kruty, Kyiv, Ukraine
}

\title{
VECTOR-SPACE APPROACH TO EVALUATION OF THE EFFICIENCY OF USE OF RADIOELECTRONIC CONTROLS
}

\begin{abstract}
The intensive development of information and control technologies, as well as their integration into a single information space, leads to an increase in the role of such technologies in the processes of control of troops (forces) and weapons, including high-precision. At the same time, the electronic material basis of information infrastructure, created within the framework of the concept of a network-centric war, is potentially vulnerable to the devices of electronic warfare. However, the analysis of the experience of using electronic devices has shown that in practice there are cases where the level of effectiveness of the use of these devices is lower than necessary. Accordingly, the improvement of the effectiveness of electronic warfare devices is an important area of scientific research. The primary component of increasing the effectiveness of electronic warfare devices is the substantiation and development of indicators that provide an objective assessment of the effectiveness of the use of these tools, taking into account all the important factors and conditions (including inaccuracies or uncertainties about the parameters of suppressed objects). Accordingly, the article develops an approach to the selection of indicators for assessing the effectiveness of the use of electronic warfare devices. The basis of the proposed approach is that the potential ability of the devices of electronic warfare to perform the tasks set forth is sufficiently fully described by the corresponding vector space, each point of which is determined by the corresponding vector, which includes a certain number of indicators describing the properties of these devices. In the course of the research, the main provisions of the theory of electronic warfare, the method of analysis of hierarchies, as well as general scientific methods of analysis and synthesis were used. The proposed approach to the evaluation of the effectiveness of the use of electronic warfare devices allows us to use a combination of system-resource approach to calculate indicators on the basis of the multilevel description of the composition of the devices of electronic warfare, when the multi-dimensional structure of its integral index (level of functioning) is gradually filled with parametric content, which is the advantage of this methodological approach. Also, the developed approach to evaluation allows us to develop, on a quantitative basis, recommendations on the choice of rational indicators of the composition of electronic warfare in accordance with the tasks set, to determine the level of functioning of the devices of electronic warfare by converting their partial and aggregate indicators.
\end{abstract}

Keywords : electronic warfare; using of devices; evaluation of efficiency; indicators and evaluation criteria.

\section{Introduction}

The intensive development of information and other advanced technologies, as well as their integration into the information-control systems of the armed forces of the leading countries of the world, the continuation of the implementation of the principles of "network-centric concept" management of troops and weapons become the most important factor determining the course and outcome of modern armed struggle. At the same time, the electronic material basis of the information infrastructure of the "network-centric concept" for conducting a modern armed struggle is potentially vulnerable to the impact of radiocommunication facilities and, accordingly, is the direct object of such influence [1-3].

Nowadays, significant progress has been made in the leading countries of the world in the development of radiocommunication facilities, which has increased the capabilities of the latter $[4,5]$. However, in practice, there are cases where there is a contradiction between the achieved and necessary levels of effectiveness of radiocommunication facilities. In the presence of this contradiction in terms of efficiency, there is a problem of finding ways to increase it.

One of the primary components of increasing the efficiency of technical devices (including radiocommunication devices) is the substantiation of objective indicators for evaluating their effectiveness, taking into account the influence of all significant factors and conditions (including inaccuracies or uncertainties about suppressing objects).

At the same time, the efficiency indicators should be rational, that is, those in which the devices of radiocommunication meet the requirements that they are put forward to the maximum, and the cost of resources for their improvement does not exceed the specified objective restrictions.

The possibility of a comprehensive practical confirmation of the rationality of the indicators of the effectiveness of radiocommunication facilities is somewhat limited. Therefore, the role and importance of methodological support for the development of adequate managerial decisions regarding the use of radiocommunication facilities, as well as their further development, is enhanced.

The purpose of this article is to develop an approach to assess the effectiveness of the use of radioactive contamination.

\section{Presentation of the main material}

The article gives an approach to the choice of the indicated rational indicators for assessing the effectiveness of radiocommunication facilities on the basis of the assumption that their potential ability to perform the tasks can be described by the corresponding vector space, each point of which is determined by a 
vector, which includes certain quantitative indicators that reflect the corresponding properties of radiocommunication facilities .

The integral index of the state of a given set of radiocommunication devices can be calculated by convolution of partial indicators, which reflect: quantitative and qualitative composition; structure of the radiocommunication system; equipment radiocommunication devices; tactical and technical characteristics of radiocommunication equipment; possibilities for restoring radiocommunication facilities; the state of the infrastructure facilities that provide a radiocommunication system, etc. [6-12].

Adhering to the principles of system analysis in the interest of choosing an adequate system of indicators, it is advisable to provide a set of radiocommunication facilities in the form of the systems hierarchy. This approach is used in the practice of research of hierarchical multi-level military systems [612].

The system of radio-contradiction includes a set of common purpose shared functions of its functional subsystems and can be described by a vector of indicators characterizing the contribution of the latter to the level of functioning of the system of radiocontradiction:

$$
E^{L M}=\left(E^{L M_{1}}, E^{L M_{2}}, \ldots, E^{L M_{n}}, \ldots, E^{L M_{N}}\right),
$$

where $E_{n}^{L M}$ is the level of functioning of the $n$-th of the functional subsystem; $N$ is the number of functional subsystems.

Under the functional subsystems of the system of radio-contradictions of membership levels are understood subsystems: radio electronic opposition (REO), control, radio-electronic information and technical support (RIS, TS).

The REO subsystem includes organizational forms that are used to disrupt management. The subsystem of control of the radiocommunication system includes: the control bodies; control points; communication and data communication system. Then, each functional subsystem can be described by a vector of indicators that characterize the contribution of its elements in the membership level of the functional subsystem:

$$
E^{F S}=\left(E^{F S_{1}}, E^{F S_{2}}, \ldots, E^{F S_{k}}, \ldots, E^{F S_{K}}\right),
$$

where $E_{k}^{F S}$ is the level of affiliation of the $k$-th element of a functional subsystem; $K$ is the number of elements in the functional subsystem.

Indicators of the effectiveness of radiocontradiction, both qualitative and quantitative, in aggregate reflect the state, divided into integral, generalized and partial [4]. The integral index of the system of radioactivity of the corresponding level of membership, which characterizes the level of functioning of the system, is the convolution of the generalized indexes of its functional subsystems, whose elements, in turn, are characterized by sums of partial indicators.
In the formalized form, the integral index of the radio-collision system of the corresponding level of affiliation can be described as follows:

$$
E^{L M}=F[R(t), U(t), Q(t), Y(t)],
$$

where $E^{L M}$ is the the level of functioning of the radiocontradiction level of affiliation at the time $t$ (on the $\ell$ th stage) of the period $T, t \in T$;

$R(t), U(t), Q(t)$ is the generalized indicators (operating levels) of subsystems of the radiocontradiction system;

$Y(t)$ is the conditions of development of radiocommunication facilities.

Level of functioning of the radiocommunication subsystem in conditions $Y(t)$ is defined by the expression [6-12]:

$$
R(t)=f_{1}\left(r^{d i s}, r^{d e f}, Y(t)\right),
$$

where $r^{d i s}, r^{d e f}$ are the levels of organization of the organizational units of the radiocommunication subsystem, used to manage and protect their organizational formations. In turn:

$$
r^{\text {dis }}(t)=f_{2}\left(\left\{r_{1}^{e f f}\right\},\left\{r_{1}^{\text {vqua }}\right\},\left\{r_{1}^{\text {per }}\right\},\left\{r_{1}^{\text {map }}\right\}\right),
$$

where $\left\{r_{1}^{e f f}\right\}$ are the partial indicators that characterize the proportion of radio-electronic devices effectively suppressed;

$\left\{r_{1}^{v q u a}\right\}$ are the partial indicators that characterize a qualitative state of devices of radiocommunication;

$$
\begin{aligned}
& \left\{r_{1}^{\text {per }}\right\} \text { are the partial figures for staffing; } \\
& \left\{r_{1}^{\text {map }}\right\} \text { are the partial indicators that characterize }
\end{aligned}
$$
the method of using radioactive contamination;

Depending on the value of the indicator $r^{\operatorname{def}}(t)$, it can be described as follows:

$$
r^{\text {def }}(t)=f_{3}\left(\left\{r_{m}^{e f f}\right\},\left\{r_{m}^{\text {wqua }}\right\},\left\{r_{m}^{\text {per }}\right\},\left\{r_{m}^{\text {map }}\right\}\right) .
$$

Level of functioning of the subsystem of control of the system of radiocommunication in the conditions $Y(t)$ is defined by the expression:

$$
U(t)=f_{4}\left(u^{g o v b}(t), u^{\text {comp }}(t), u^{a u e q}(t) Y(t)\right),
$$

where $u^{\text {govb }}(t), u^{\text {comp }}(t), u^{\text {aueq }}(t)$ are levels of operation of the control elements of the radiocommunication subsystem, systems and devices of automation and communication.

Thus, partial indicators that quantitatively characterize the system of radio-contradiction, taking into account the classes of radio-electronic devices (RED), can be described in the form as shown in the table.1. 
Table 1 - System of indicators for evaluation of the radiocommunication devices

\begin{tabular}{|c|c|}
\hline The name of a set of indic & Name of indicators \\
\hline \multirow{9}{*}{$\begin{array}{l}\begin{array}{l}\text { Indicators of the state } \\
\text { (effectiveness) of }\end{array} \\
\text { radiocommunication devices } \\
\left\{r_{l}^{e f f}\right\}, l \in L \\
\left\{r_{m}^{e f f}\right\}, m \in M\end{array}$} & - the proportion of satellite-based RED that are effectively suppressed \\
\hline & - the proportion of short-wave short-wave RED that are effectively suppressed \\
\hline & $\begin{array}{l}\text { - the proportion of ultra short-wave RED frequency rejection that is effectively } \\
\text { suppressed }\end{array}$ \\
\hline & - the proportion of RED tropospheric communication that is effectively suppressed \\
\hline & - the proportion of RED that are effectively suppressed \\
\hline & - the proportion of RED of effectively transmitting information systems \\
\hline & - the proportion of homing heads that are effectively suppressed \\
\hline & $\begin{array}{l}\text { - the share of REs for land and air users of navigation systems ("Navstar", "Glonass", } \\
\text { "Beidou", etc.) that are effectively suppressed }\end{array}$ \\
\hline & $\begin{array}{l}\text { - The proportion of radio-controlled blasting of artillery and other ammunition that are } \\
\text { effectively suppressed }\end{array}$ \\
\hline \multirow{4}{*}{$\begin{array}{l}\text { Indicators of the state (qualitative } \\
\text { aspect) of the devices of } \\
\text { radiocommunication } \\
\left\{r_{l}^{\text {vqua }}\right\}, l \in L \\
\left\{r_{m}^{\text {vqua }}\right\}, m \in M\end{array}$} & - staffing with the devices of radiocommunication \\
\hline & - coefficient of technical readiness of radiocommunication devices \\
\hline & - noise immunity of radiocommunication devices \\
\hline & - the level of potential of modernization of radiocommunication devices \\
\hline $\begin{array}{l}\text { Indicator of personnel } \\
\quad \text { completeness } \\
\left\{r_{l}^{\text {per }}\right\}, l \in L ; \quad\left\{r_{m}^{\text {per }}\right\}, m \in M\end{array}$ & - the level of staffing of the units in peacetime in the appropriate direction of training \\
\hline \multirow{7}{*}{$\begin{array}{l}\text { Indicators that characterize the } \\
\text { method of using radioactive } \\
\text { contamination } \begin{array}{l}\left\{r_{l}^{\text {map }}\right\}, l \in L \\
\left\{r_{m}^{\text {map }}\right\}, m \in M\end{array}\end{array}$} & $\begin{array}{l}\text { - Percentage of radiocommunication devices that are capable of performing the tasks in } \\
\text { motion (at short stops) }\end{array}$ \\
\hline & $\begin{array}{l}\text { - the level of correspondence of the real time of deployment (collapse) of the devices of } \\
\text { radiocommunication necessary }\end{array}$ \\
\hline & - the possibility of secret operation of radiocommunication facilities \\
\hline & $\begin{array}{l}\text { - the robustness of the work of the radio-contradiction devices in the conditions of their } \\
\text { damage by the enemy's fire-fighting equipment, electromagnetic radiation and weapons } \\
\text { with self-propagation to radiation }\end{array}$ \\
\hline & $\begin{array}{l}\text { - the ability of radioactivity to adapt to the physical and geographical conditions of its } \\
\text { application }\end{array}$ \\
\hline & - adaptability to the implementation of new forms use \\
\hline & - adaptability in a network-centric way of deployment \\
\hline
\end{tabular}

In turn:

$$
u^{\text {govb }}(t)=f_{5}\left(\left\{u^{\text {org }}\right\},\left\{u^{\text {inf }}\right\}\right)
$$

where $\left\{u^{\text {org }}\right\}$ are the Partial indicators that characterize the quality of organization of management of the devices of radio contradiction;

$\left\{u^{\text {inf }}\right\}$ are the partial indicators that characterize the level of information security management by the devices of radiocommunication.

To the partial indicators $\left\{u^{\text {org }}\right\}$ belong:

$u^{\text {sit }}$ is the level of compliance of the organization of management of the current composition of the objectives and objectives of the radiocommunication, new forms and methods of the use of the devices of radiocommunication;

$u^{\text {stoc }}$ is the level of staffing of radioactive control authorities by the relevant specialists; $u^{\text {int }}$ is the level of implementation of modern algorithms of support and decision-making;

$u^{s t r}$ is the possibility of timely structural and parametric adaptation to changes in the electronic environment;

$u^{\text {net }}$ is the level of implementation of the networkcentric management method;

$u^{\text {con }}$ is the level of compliance of the organizational structure of the control system by the devices of radio resistance to the management norms.

Partial Indicators $\left\{u^{\text {inf }}\right\}$ include:

$\left\{u^{\text {plan }}\right\}$ is the level of compliance with the information provision while planning the use of radio equipment to the necessary;

$\left\{u^{\text {conf }}\right\}$ is the level of compliance of information support with the direct control of the devices of radio resistance to the necessary; 
$\left\{u^{m n}\right\}$ is the length of the cycle of extraction, collection and transmission of data on radio-electronic objects from all sources in relation to the required;

$\left\{u^{f u l}\right\}$ is the period of the complete updating of the situation data;

$\left\{u^{r e m}\right\}$ is the level of compliance with the duration of the disturbed management to the required.

Level of the control points operation:

$$
u^{\text {govb }}(t)=f_{6}\left(\left\{u^{\text {tech }}\right\},\left\{u^{\text {func }}\right\}\right),
$$

where $\left\{u^{\text {tech }}\right\}$ are the partial indicators that reflect the technical equipment of control points;

$\left\{u^{\text {func }}\right\}$ are the partial indicators that characterize the operation of control points.

To the partial indicators $\left\{u^{\text {tech }}\right\}$ belong:

$u^{e q}$ is the level of equipment controls;

$u^{\text {soft }}$ is the level of information and special software;

$u^{l e v}$ is the level of equipment items management by appropriate devices;

$u^{\text {mat }}$ is the level of conjugation of automated systems and devices of radiocommunication with interacting systems;

$u^{\text {exc }}$ is the level of organization of the exchange of information about the radio-electronic situation with interacting systems.

Partial indicators $u^{\text {func }}$ include:

$u^{c y c l}$ is the level of compliance with the duration of the organization of the use of radioactive equipment to the necessary;

$u^{\text {dircycl }}$ is the level of correspondence of the cycle of direct control by the devices of radiocommunication to the necessary;

$u^{d e p}$ is the level of correspondence of the time of deployment and preparation for the work of the radiocommunication control point to the necessary;

$u^{t r}$ is the level of correspondence of the time of transfer of control from one control point to another to the required;

$u^{\text {rest }}$ is the time of restoration of the disturbed control of the devices of radiocommunication to the necessary;

$u^{d e f}$ is the level of protection of control points from technical devices of intelligence;

$u^{\text {defd }}$ is the level of protection of radio control points from the influence of the devices of damage:

$$
\begin{gathered}
u^{\text {aueq }}(t)= \\
=f_{7}\left(u^{\text {int eg }}, u^{\text {compat }}, u^{\text {direc }}, u^{\text {spec }}, u^{\text {mod }}\right) \text {, }
\end{gathered}
$$

where $u^{\text {int } e g}$ is the level of integration of the automated control system by the devices of radio-contradiction in the network-centric-oriented technical basis of the radio-control system;

$u^{\text {compat }}$ are the levels of compatibility of existing (those coming to the arms) automation of control points at different levels of management;

$u^{\text {direc }}$ is the timeliness of receiving, processing, displaying and transmitting policy documents, commands and signals;

$u^{\text {spec }}$ is the level of special protection of transmission and processing of information;

$u^{\text {mod }}$ is the level of equipment management information-modeling complexes.

Level of functioning of subsystems of radioelectronic and technical maintenance of control units in the conditions $Y(t)$ is defined by the expression [6-12]:

$$
\begin{gathered}
Q(t)= \\
=f_{8}\left(\left\{q^{\text {intel }}(t)\right\},\left\{q^{\text {cts }}(t)\right\},\left\{q^{i w}(t)\right\},\left\{q^{t s}(t)\right\} Y(t),\right),
\end{gathered}
$$

where $\left\{q^{\text {intel }}(t)\right\}$ are the partial indicators that reflect the effectiveness of spacious-spaced radio intelligence systems that are used in the interests of the radioresistance system;

$\left\{q^{c t s}(t)\right\}$ are the partial indicators that characterize the effectiveness of comprehensive technical control of masking and radio-electronic security measures;

$q^{i w}(t)$ are the partial indicators that reflect the quality of information work of agencies and radiocommunication control facilities;

$q^{t s}(t)$ are the partial indicators of the subsystem of the technical support of radiocommunication devices.

In turn:

$$
q^{\text {intel }}(t)=f_{9}\left\{q^{\text {reo }}, q^{\text {bandin }}, q^{\text {rangin }}, q^{\text {fir }}\right\}
$$

where $q^{\text {reo }}$ is the level of correspondence of the achieved time of detection of objects with given confidence in the area of responsibility to the required;

$q^{\text {bandin }}$ is the level of correspondence of the real width of the intelligence band of radio-electronic objects by the devices of radio-resistance to the necessary;

$q^{\text {rangin }}$ is the level of correspondence of the real range of intelligence of radio-electronic objects by the devices of radio-resistance to the necessary;

$q^{f i r}$ is the level of protection of forces and devices of technical intelligence from the devices of fire and radio-electronic defeat.

$$
q^{c t s}(t)=f_{10}\left(q^{\text {opts }}, q^{\text {fulcon }}\right)
$$


$q^{\text {opts }}$ is the level of correspondence of the achieved time of receipt and bringing to the management bodies of the results of an integrated assessment of the state of protection of objects and organizational-staff structures from the technical devices of intelligence (operational control);

$q^{\text {fulcon }}$ is the proportion of its objects that is covered by the control (completeness of coverage by the control).

$$
q^{i w}(t)=f_{11}\left(q^{\text {sour }}, q^{i n}, q^{\text {met }}, q^{\text {coop }}\right)
$$

where $q^{\text {sour }}$ is the level of compliance of the achieved time of data collection of the electronic environment from all sources of information with the given confidence to the required;

$q^{i n}$ is the degree of integration of the information resources of the bodies and points of control of the radiocommunication into a single information space;

$q^{\text {met }}$ is the proportion of new methods and tools for the collection, processing, presentation and use of radio electronic data to increase the level of adaptation of automated systems and devices of the radioactivity control to its change;

$q^{\text {coop }}$ is the level of information interaction with the joint execution of tasks.

$$
q^{t s}(t)=f_{12}\left(q^{r e p}, q^{\text {back }}, q^{\text {pack }}, q^{t r}\right),
$$

where $q^{\text {rep }}$ is the share of promising tools and new technologies for maintenance and repair of the radio equipment;

$q^{\text {back }}$ is the percentage of repayment after the repair;

$q^{\text {pack }}$ is the level of compliance of the equipment of the radiocommunication equipment, other material resources in the places of their storage to the requirements that are put forward to them;

$q^{t r}$ is level of staffing with modern training equipment.

Taking into account (3) the integral index

$$
E=F\left[\begin{array}{l}
R(t), U(t), Q(t), Y(t), f_{12} \\
\left(\left\{z_{j}(t)\right\},\left\{n_{i j}(t)\right\},\left\{c_{j}(t)\right\}\right)
\end{array}\right],\left\{z_{j}(t)\right\}
$$

is the set of tasks assigned to the system of radiocontradiction, in $j$-th variant of its development, $z \in Z$;

$\left\{n_{i j}(t)\right\} \quad$ is a system of measures for the development of a system of radiocommunication aimed at changing $i$-th $(i \in l)$ inducators in $j$-th variant of its development, $n \in N$;

$\left\{c_{j}(t)\right\}$ are the resources allocated for implementation $j$-th variant of development of the system of radio-contradiction, $j \in J$;
$I, N, Z, J$ is a set of indicators, development measures, variants of the list of tasks assigned to systems of radio-contradiction, and variants of its development.

For the quantitative assessment of the impact of the development measures on the indicators of the radiocommunication system, the latter can be described as follows [6-12]:

$$
\left\{\prod_{i j}(t)\right\}=\left\{\frac{\prod_{i}^{0}(t)+\Delta \prod_{i j}\left(z_{j}, n_{i j}, c_{j}, t\right)}{\prod_{i j}^{r e q}(t)}\right\},
$$

$\prod_{i}^{0}(t)$ is the size of $i$-th indicator of the beginning of $t$-th period;

$\Delta \prod_{i j}\left(z_{j}, n_{i j}, c_{j}, t\right)$ is the changes in size of $i$-th indicator during $n_{i j}$-th event of the development of the system of radiocommunication, $c_{j}$-th volume of the resources, that are allocated in the $j$-th development option on the $t$-th phase of the period;

$\prod_{i j}^{r e q}(t)$ is the required level of the $i$-th indicator at the $j$-th development option on the $t$-th stage of the planning period.

The following restrictions apply to the indicators of the system of radiocommunication:

$$
\prod_{i j}^{0}(t)+\Delta \prod\left(z_{j}, n_{i j}, c_{j}, t\right) \leq \prod_{i}^{r e q}(t) \geq 0 .
$$

Definition of quantitative values of indicators of the system of radio-contradiction is carried out in the process of calculating the potential of $j$-th variants of the plan for the development of the radio-contradiction system by analyzing the effectiveness of the development of the system of radio-contradiction and the importance of the components of the radioresistance system using the method of analysis of hierarchies.

In accordance with the structure of the system of indicators (Table 1), the proposed vector-spatial approach to the evaluation of the effectiveness of the radio-protection system includes the following steps:

The 1-st stage is an assessment of the effectiveness of the implementation of the first option of the development plan. Each measure is subject to a comprehensive assessment regarding: degree of influence on partial parameters of elements of functional subsystems of radio-contradiction, conformity of the concept of development of radio-resistance means to the tendencies of development of information management systems of the leading countries of the world, resource intensiveness and possibilities of realization in the given perspective. Taking into account the influence of factors, including financial, economic, military-technical, technical and technological, organizational in the manner indicated in [5].

2-nd stage is the evaluation of the levels of functioning of the elements of the functional subsystems of the radio-contradiction by the formula: 


$$
E_{k}^{E}=\sum_{i} \gamma_{i j} \prod_{i j}(t)
$$

3-rd stage is the evaluation of the levels of functioning of the functional subsystems of the radiocontradiction system by the formula:

$$
E_{n}^{F S}=\sum_{k=1}^{K} \gamma_{k j} E_{k}^{E}
$$

4-th stage is the assessment of the level of functioning of the radiocommunication system as a whole by the formula:

$$
E_{m}^{L M}=\sum_{n=1}^{N} \gamma_{n j} E_{n}^{F S},
$$

where $\gamma_{i j}, \gamma_{k j}, \gamma_{n j}$ is the importance of the $i$-th indicator of the $k$-th element of the $n$-th functional subsystem of the system of radioactivity at $j$-th variant of development, respectively.

The coefficients of the significance of components of the system of radio-contradiction and their partial indicators can be calculated by the method of pair comparisons using the universal scale T. Saati [6-12].

Increase in the values of each partial index of the radio-collision system $\Delta \prod_{i j}\left(z_{j}, n_{i j}, c_{j}, t\right)$ as a result of implementation of the $n_{i j}$-th actions of the $j$-th The development option is determined using the expert judgment.

In determining this increase, two cases are possible.

1. The indicator $\prod_{i j}^{0}(t)$ is set quantified. For examle, $r^{\text {moder }}$ is the staffing of the radiocommunication unit with modern models of radio equipment technology. It is known that the staffing of the radiocommunication subsystem of the radiocommunication subsystem with modern models of radio equipment technology before the beginning of the program period is $60 \%$. The deployment during the program period of an additional radiocommunication unit in this subsystem, equipped with radio-technology of the same class, allows precisely to determine the value of growth $\Delta \prod_{i j}\left(z_{j}, n_{i j}, c_{j}, t\right)$, which will be, for example, $20 \%$.

Then the value of the analyzed index by the end of the software period $\prod_{i j}^{0}(t)$ will take the value of $80 \%$.

2. The indicator $\prod_{i j}^{0}(t)$ is set quality. For example, the indicator $q^{\text {in }}$ is degree of integration of information resources of the radiocommunication control body into a single information space. The increment of this indicator can be determined as follows. The decision maker shall submit a list of measures that must be taken to conclude that the full integration of information resources. Knowing what steps have already been taken before the start of the planning period, you can decide on the place where implementation of a particular event with $j$-th option and the expert approach to assess it quantitatively as

$$
\Delta \prod_{i j}\left(z_{j}, n_{i j}, c_{j}, t\right) .
$$

Obtained as a result of the solution of the formulated problem, the values of the components of the system of radio-contradiction, form the maximum value of the indicator $E_{m}^{L M}$, which is grouped by the components $\{r(t)\},\{u(t)\},\{q(t)\}, \quad$ are considered rational for the implementation of a set of tasks $\mathrm{Z}$, assigned to it in a given program period.

It is also necessary to take into account that the conduct of each measure may lead to changes in the values of several indicators.

For example, the deployment of a new radiocommunication unit will change the quantitative ratio of new and old technology, its staffing of various categories, etc.

\section{The conclusion from the article}

Thus, the proposed vector-spatial approach to the evaluation of the effectiveness of the use of electronic countermeasures allows:

the use of a combination of system-resource approach to the calculation of indicators on the principle of multi-level description of the radio-contradiction system, when the multidimensional structure of its integral index (level of functioning) is gradually supplemented by parametric content;

on a quantitative basis, to make recommendations on the choice of rational indicators of the radiocommunication system in accordance with its tasks in the planned period;

to determine the level of functioning of the system of radio-contradiction by converting partial and aggregate indicators with an attachment to the tasks assigned to them;

to comprehensively take into account the influence of the development of the components of the system of radio-resistance on the change of their indicators, to analyze intermediate results and to identify patterns on this basis, which explain the reasons behind the development of some components of the system of radio-contradiction from others;

to identify a rational set of measures to improve the system of radio-contradiction, which will allow them to end the program period from the initial state to the assignment, in which it will most fully meet the requirements imposed by the allocated resources;

in advance to create in the regulatory bodies of radio control regulatory and calculation basis for planning the development of components of the system of radio-resistance in a given perspective.

The direction of further researches should be taken into account during the evaluation of the effectiveness of the system of radio-contradiction of the conditions of uncertainty regarding the objects and devices of the opposing side. 
1. Alimpiyev, A.M. and Pevtsov, G.V. (2017), "Features of the hybrid war against the Russian Federation. Experience gained by the Air Forces of the Armed Forces of Ukraine", Science and Technology of the Air Forces of the Armed Forces of Ukraine, No. 2(27), pp. 19-25, DOI: https://doi.org/10.30748/nitps.2017.27.03.

2. Bogdanovich, V.Yu., Svida, I.Yu. and Syrotenko, A.M. (2018), "The concept of the integrated use of military and nonmilitary forces and means to ensure a sufficient level of military security of the state ", Science and Technology of the Air Forces of the Armed Forces of Ukraine, No. 2(31), pp. 16-29, DOI: https://doi.org/10.30748/nitps.2018.31.02.

3. Radiyevskiy, A.G. and Sirota, A.A. (2004), Theoretical foundations of electronic intelligence, Moscow, pp. 3-29.

4. Shyshatskiy, A.V., Bashkirov, O.M. and Kostina, O.M. (2015), "Development of integrated systems and data for Armed Forces", Arms and military equipment, No 1(5), pp. 35-40.

5. Hatsenko, S.S. (2017), "Methodology for assessing the operational situation in automated control systems of troops under uncertainty", Science and Technology of the Air Forces of the Armed Forces of Ukraine, No. 1(26), pp. 101-105. DOI: https://doi.org/10.30748/nitps.2017.26.21.

6. Kalantaievska, S., Pievtsov, H., Kuvshynov, O., Shyshatskyi, A., Yarosh, S., Gatsenko, S., Zubrytskyi, H., Zhyvotovskyi, R., Petruk, S. and Zuiko, V. (2018), "Method of integral estimation of channel state in the multiantenna radio communication systems.", Eastern-European Journal of Enterprise Technologies, Vol 5, No 9 (95): pp 60-76. DOI: https://doi.org/10.15587/1729-4061.2018.144085.

7. Zhuk, O.G., Shyshatskiy, A.V., Zhuk, P.V. and Zhyvotovskyi, R.M. (2017), "Methodological substances of management of the radio-resource managing systems of military radio communication", Information Processing Systems, Vol. 5(151), pp. 16-25, DOI: https://doi.org/10.30748/soi.2017.151.02.

8. Babul, V.A. and Sverbut, A.M. (2014), Control systems and radio engineering foreign armed forces, Part 1, Minsk, 263 p.

9. Kuvshinov, O.V., Shyshatskiy, A.V., Lyutov, V.V and Zhuk, O.G. (2017), "Analysis of ways for increasing the secrecy of broadband radiocommunication systems", Scientific works of Kharkiv National University of Air Forces, No. 1(50), pp. 24-28.

10. Popov, A.O., Tverdokhlibov, V.V(2014). "General tendencies of development of means of electronic warfare ", Arms and military equipment, No. 4 (4), pp. 4-10.

11. Serhiienko, V.D., Popov, A.O., Zibin, S.D., Bychkov, A.N. and Pidhorodetskyi, M.M. (2017), "Analysis of the state of the art of multifunctional electronic warfare means and complexes", Modern Information Technologies In the sphere of security and defence, No.1(28), pp.135-143.

12. Romanenko, I. and Shyshatskyi, A. (2017), "Analysis of modern condition of military radiocommunication system", Advanced Information Systems, Vol. 1, No. 1, pp. 28-33, DOI: https://doi.org/10.20998/2522-9052.2017.1.05.

Надійшла (received) 17.07.2019

Прийнята до друку (accepted for publication) 28.08.2019

\section{ВідОмості Пто АвтоРів / AвOUT THE AUTHORS}

Шишацький Андрій Володимирович - кандидат технічних наук, начальник науково-дослідної лабораторії, Центральний науково-дослідний інститут озброєння та військової техніки Збройних Сил України, Київ, Україна; Andrii Shyshatskyi - Candidate of Technical Sciences, Head of the science-research laboratories, Central Research Institute of Weapons and Military Equipment of Armed Forces of Ukraine, Kyiv, Ukraine; e-mail: ierikon12@gmail.com; ORCID ID: http://orcid.org/0000-0001-6731-6390

Журавський Юрій Володимирович - доктор технічних наук, старший науковий співробітник, провідний науковий співробітник наукового центру, Житомирський військовий інститут імені С. П. Корольова, Житомир, Україна;

Yurii Zhuravskyi - Doctor of Technical Sciences, Senior Research, Lead Researcher of the science-Center, Zhytomyr Military Institute named after S. P. Korolev, Zhytomyr, Ukraine;

e-mail: zhurr@ukr.net; ORCID ID: http://orcid.org/0000-0002-4234-9732

Кувшинов Олексій Вікторович - доктор технічних наук, професор, заступник нкчальника навчально-наукового інституту, Національний університет оборони України імені Івана Черняховського, Київ, Україна;

Alexey Kuvshinov - Doctor of Technical Sciences, Professor, Deputy Chief of Educational-Scientific Institute, National Defence University of Ukraine named after Ivan Chernyakhovsky, Kyiv, Ukraine; e-mail: kuvsh@ukr.net; ORCID ID: http://orcid.org/0000-0002-4341-2123

Гурський Тарас Григорович - кандидат технічних наук, доцент, докторант, Військовий інститут телекомунікацій та інформатизації імені Героїв Крут, Київ, Україна;

Taras Hurskyi - Candidate of Technical Sciences, Associate Professor, Doctoral Student, Military institute of telecommunications and informatization named after Heroes of Kruty, Kyiv, Ukraine; e-mail: 5025572@gmail.com; ORCID ID: https://orcid.org/0000-0001-7646-853X

Возняк Роман Миколайович - ад’юнкт, Національний університет оборони України імені Івана Черняховського, Київ, Україна;

Roman Vozniak - adjunct, National Defence University of Ukraine named after Ivan Chernyakhovsky, Kyiv, Ukraine, Ukraine; e-mail: Roman.Vozniak@gmail.com; ORCID ID: http://orcid.org/0000-0002-3789-2837

Пікуль Ростислав Володимирович - слухач, Національний університет оборони України імені Івана Черняховського, Київ, Україна;

Rostislav Pikul - hearer, National Defence University of Ukraine named after Ivan Chernyakhovsky, Kyiv, Ukraine, Ukraine; e-mail: plkul.rostislav@gmail.com; ORCID ID: http://orcid.org/0000-0003-3928-9596 
Пікуль Ольга Ігорівна - слухач, Національний університет оборони України імені Івана Черняховського, Київ, Україна; Olga Pikul - hearer, National Defence University of Ukraine named after Ivan Chernyakhovsky, Kyiv, Ukraine, Ukraine; e-mail: plkul.olga@gmail.com; ORCID ID: http://orcid.org/0000-0001-5495-5943

\section{Векторно-просторовий підхід до оцінювання ефективності застосування засобів радіоелектронної протидії}

А. В. Шишацький, Ю. В. Журавський, О. В. Кувшинов,

Т. Г. Гурський, Р. М. Возняк, Р. В. Пікуль, О. І. Пікуль

Анотація. Інтенсивний розвиток інформаційних та управляючих технологій, а також їх інтеграція в єдиний інформаційний простір приводить до підвищення ролі таких технологій у процесах управління військами (силами) та зброєю, у тому числі високоточною. Разом із тим, радіоелектронна матеріальна основа інформаційної інфраструктури, що створюється в рамках концепції мережецентричної війни, є потенційно уразливою для засобів радіоелектронної протидії. Проте, аналізу досвіду використання засобів радіоелектронної протидії показав, що на практиці мають місце випадки, коли досягнутий рівень ефективності застосування цих засобів є нижчим за необхідний. Відповідно, удосконалення ефективності засобів радіоелектронної протидії $\epsilon$ актуальним напрямком наукових досліджень. Первинною складовою збільшення ефективності засобів радіоелектронної протидії $\epsilon$ обгрунтування та розроблення показників, які забезпечують об’ єктивне оцінювання ефективності застосування цих засобів з урахуванням усіх вагомих чинників та умов (у тому числі неточності або невизначеності щодо параметрів об'єктів подавлення). Відповідно, у статті розроблено підхід щодо вибору показників оцінювання ефективності застосування засобів радіоелектронної протидії. В основу запропонованого підходу покладено те, що потенційна здатність засобів радіоелектронної протидії виконувати поставлені завдання достатньо повно описується відповідним векторним простором, кожна точка якого визначається відповідним вектором, що включає певну кількість показників, які описують властивості цих засобів. У ході проведеного дослідження було використано основні положення теорії радіоелектронної протидії, метод аналізу ієрархій, а також загальнонаукові методи аналізу та синтезу. Запропонований підхід до оцінювання ефективності застосування засобів радіоелектронної протидії дозволяє використовувати комбінацію системно-ресурсного підходу до розрахунків показників за принципом багаторівневого опису складу засобів радіоелектронної протидії, коли багатомірна структура ії інтегрального показника (рівня функціонування) поступово наповнюється параметричним наповненням, що $\epsilon$ перевагою даного методичного підходу. Також розроблений підхід до оцінювання дозволяє розробляти на кількісній основі рекомендації з вибору раціональних показників складу засобів радіоелектронної протидії відповідно до поставлених завдань, визначати рівень функціонування засобів радіоелектронної протидії шляхом згортки їх часткових та узагальнених показників.

Ключові слов а : радіоелектронна боротьба; застосування засобів; оцінювання ефективності; показники та критерії оцінювання.

\section{Векторно-пространственный подход}

\section{к оценке эффективности применения средств радиоэлектронного противодействия}

А. В. Шишацкий, Ю. В. Журавський, А. В. Кувшинов,

Т. Г. Гурский, Р. Н. Возняк, Р. В. Пикуль, О. И. Пикуль

Аннотация. Интенсивное развитие информационных и управляющих технологий, а также их интеграция в единое информационное пространство приводит к повышению роли таких технологий в процессах управления войсками (силами) и оружием, в том числе высокоточного. Вместе с тем, радиоэлектронная материальная основа информационной инфраструктуры, создаваемой в рамках концепции сетецентрической войны, потенциально уязвима для средств радиоэлектронного противодействия. Однако, анализа опыта использования средств радиоэлектронного противодействия показал, что на практике имеют место случаи, когда достигнутый уровень эффективности применения этих средств ниже необходимого. Соответственно, совершенствование эффективности средств радиоэлектронного противодействия является актуальным направлением научных исследований. Первичной составляющей повышения эффективности средств радиоэлектронного противодействия является обоснование и разработка показателей, обеспечивающих объективное оценивание эффективности применения этих средств с учетом всех значимых факторов и условий (в том числе неточности или неопределенности относительно параметров объектов подавления). Соответственно, в статье разработан подход по выбору показателей оценки эффективности применения средств радиоэлектронного противодействия. В основу предлагаемого подхода положено то, что потенциальная способность средств радиоэлектронного противодействия выполнять поставленные задачи достаточно полно описывается соответствующим векторным пространством, каждая точка которого определяется соответствующим вектором, включая определенное количество показателей, которые описывают свойства этих средств. В ходе проведенного исследования были использованы основные положения теории радиоэлектронного противодействия, метод анализа иерархий, а также общенаучные методы анализа и синтеза. Предложенный подход к оценке эффективности средств радиоэлектронной борьбы позволяет использовать комбинацию системно-ресурсного подхода к расчетам показателей по принципу многоуровневого описания состава средств радиоэлектронной борьбы, когда многомерная структура ее интегрального показателя (уровня функционирования) постепенно наполняется параметрическим наполнением, что является преимуществом данного методического подхода. Также разработан подход к оценке позволяет разрабатывать на количественной основе рекомендации по выбору рациональных показателей состава средств радиоэлектронного противодействия соответствии с поставленными задачами, определять уровень функционирования средств радиоэлектронной борьбы путем свертки их частных и обобщенных показателей.

Ключевые слова: радиоэлектронная борьба; применение средств; оценки эффективности; показатели и критерии оценки. 